\title{
Methods for Selecting Ethical Investments: Some Sociological Explanations
}

\author{
Caterina Galluccio \\ Università Degli studi G. d'annunzio Di Chieti, Pescara, Itay \\ Email: caterina.galluccio@unich.it
}

How to cite this paper: Galluccio, C. (2018). Methods for Selecting Ethical Investments: Some Sociological Explanations. Advances in Applied Sociology, 8, 319-328. https://doi.org/10.4236/aasoci.2018.84018

Received: February 17, 2018

Accepted: April 20, 2018

Published: April 23, 2018

Copyright $\odot 2018$ by author and Scientific Research Publishing Inc. This work is licensed under the Creative Commons Attribution International License (CC BY 4.0).

http://creativecommons.org/licenses/by/4.0/

\begin{abstract}
Nowadays the need for an ethical and socially responsible approach to finance appears increasingly evident, yet the sphere of ethical finance does not have the success that one could imagine. This work reflects on the possible causes of this lukewarm or just partial response to ethical finance by investors and does so using the paradigm of methodological individualism as an explanatory tool, focusing in particular on the issues of individual responsibility and personal freedom.
\end{abstract}

\section{Keywords}

Social Representation, Methodological Individualism, Social and Ethical Finnace

\section{Introduction}

This essay aims to examine some of the problematic and contradictory aspects related to ethical finance-in particular to ethical investments-and to identify some possible hypotheses for explanation, without however claiming to be conclusive in a debate that is more complex than ever, especially in the current historical moment, where the estimates of the disparities between the peoples have reached values never before touched and where the only possible economic model seems to be that of the market economy, given that both the planned economy and the mixed economy have not provided alternatives effective.

If the only possible economic model is that of the market economy, the so-called push to "humanize the economy" translates into a drive to "humanize the market", and in this sense it seems to propose "alternative finance". We will consider later the contradictions contained in the two expressions "humanizing the economy" and "humanizing the market"; our purpose in this work is to 
overturn the point of view, looking at the problem not from the point of view of the offer of alternative financial instruments, but from the point of view of their demand, which is starting from the individual and his investment decisions that presuppose processes such as research, selection and finally the choice between the different alternatives.

Carl Menger taught us that the market is a spontaneous order in other words, unintentionally wanted by individuals (Menger, 1997: pp. 150-152) the kind of order that Friedrich von Hayek indicates as Cosmos (Hayek, 1994: p. 51). The stock exchange is also a Cosmos, in other words a spontaneous creation that allows the exchange of shares. The same criticisms are directed to the market: it is considered an immense casino or a lottery where one gains what others lose, suggesting that buying and selling stocks on the market men practice a zero-sum game (Salin, 2002: pp. 252-253). These criticisms, similar to those addressed to the market in general, which we will see later, seem to forget that the stock market "creates wealth, increases prosperity and allows employees to obtain higher salaries, owners to obtain greater profits, consumers of get cheaper products. And this above all because the Stock Exchange allows a better use of savings (...). If the stock market did not exist, companies would finance themselves by resorting more to credit instead of issuing shares. Yet, between these two sources of financing there is an essential difference, since only the issue of shares gives rise to property rights that are the foundation of responsibility" (Salin, 2002: p. 253). The theme of responsibility will be referred to several times in this regard both in terms of individual action and in terms of the degrees of freedom that an individual enjoys.

And speaking of action, praxeology by Ludwig von Mises teaches us that man acts to remove dissatisfaction and that human action is always rational priori-in the sense of congruity between means and ends-and economic-because the choice of an alternative presupposes the renunciation of the others (Mises, 1959: pp. 11-16, 31). Hence man is homo agens whose actions-according to methodological individualism-have intentional and unintentional consequences and above all action is not only doing, but also omitting to do what could be done. "Talking or being silent (...) can be action (...). Even the man who refrains from influencing the action of psychological and instinctive factors that could influence acts" (Mises, 1959: pp. 11-14). These considerations take on particular importance in reflecting on the active or passive nature of individual action on financial investments.

Given these premises, when it comes to "alternative finance"-meaning finance as a whole the activities aimed at finding and using capital in economic enterprises-it seems to refer to it as a res, that is a reality sui generis which imposes its rules on the individual, offering him financial instruments of one or the other type. Therefore in this image on one side there is Finance on the other side of the Individual. If it is not incorrect as a heuristic scheme, in reality this representation is undoubtedly partial because we believe that the investor must have a demand for "alternatives" among the financial instruments, and, only conse- 
quently, the offer will diversify the options of choice within the preferences expressed by the investor. This means that the primacy of the individual is the man who thinks, chooses and acts. Therefore it is not possible to attribute to the Finance or the Stock Exchange the responsibility of not offering what the individual does not demand.

These clarifications seem opportune for us to understand the role of the investor and the responsibility behind his actions (whether he does something, or does not do what could be done) and at the same time, to understand that the market as catallassi it is neither "good nor bad", but an order born spontaneously from the exchange of raw materials, commodities, money or actions, exchanges from which individuals derive satisfaction, that is, that subjective value which we will discuss later.

With this work, therefore, we will examine some aspects of ethical investments from the point of view of the economic actor trying to clarify some of the most recurring prejudices about the market and profit, in the awareness that ethical investment is a form of ethics for profit and that responds to criteria of solidarity and not charity.

\section{The Responsibility of the Ethical Investor}

The motivations that drive ethical savings may be different and in each of them there are some opportunities for the investor. In fact, ethical investment does not only satisfy an economic need, but also a social need, as it seeks to channel savings towards humanitarian purposes. But not only that, it also embodies a need for self-fulfillment in some respects because it gives the saver the chance to overcome the "pure delegation" of the past and become a protagonist, an active subject in the destination of their savings, thus acquiring a responsibility. Which responsibility?

First of all, let us begin to consider the concept of responsibility as awareness that one's own action or not acting always has consequences that are predictable or unpredictable.

"The Christian doctrine conceives the human person as a creature-by virtue of a mysterious and gratuitous act of God-to which the Creator himself entrusts and entrusts the universe. From this comes the responsibility for the person to manage the goods and the environment (as a non-owner but guardian) and, consequently—as a specifically human value and dimension-freedom, i.e. the ability to design and build one's life in order to this task" (Bedogni, 2002: p. 103).

From this it follows that the individual is free to accept or ignore this responsibility, but must nevertheless be aware that every action of his will have infinite consequences, intentional and unintentional. "Every choice and decision in the use of money or of one's own goods does not end in immediate and visible effect. Small and infinite consequences are produced, for example, by preferring one good rather than another. This certainly applies, and to a more indicative extent, for investments" (Bedogni, 2002: p. 104). And yet depositing or investing 
money always has socio-cultural and ecological consequences. An investment is therefore never neutral, it exerts a positive or negative influence on the evolution of the world and this fact must be taken into account by those who intend to use their money responsibly.

To understand what is meant by individual responsibility in economic choices regarding the question of ethical investments, it seems appropriate to recall the debate on ethics of intentions and ethics of responsibility. "We must make it clear-observes Weber-that any ethical-oriented action can oscillate between two radically different and irreconcilably opposed maxims: it can be oriented according to the ethics of conviction or according to the ethics of responsibility. Not that the ethics of conviction coincides with the lack of responsibility and the ethics of responsibility with the lack of conviction (...). But there is an unbridgeable difference between acting according to the maxim of the ethics of conviction, which-in religious terms-sounds: 'The Christian works as righteous and puts the outcome in the hands of God', and acting according to the maxim of the ethics of responsibility, according to which the consequences (foreseeable) of one's actions must be answered" (Weber, 1999: p. 109).

The ethics of intentions is undoubtedly contained in the positive assessments expressed precisely on ethical investments, considered instruments of solidarity: it is right because it is right; but the ethics of responsibility refers to the consequences of actions and it is here that the investor must understand how his actions, or even his do not act-as Mises' praxeology teaches us-in other words, ask whether or not to invest your money in ethical funds has consequences. Of these consequences he must be aware not to fall into the inevitable traps of an unjust charity or in the contradictions of those who, for example, take part in protests against multinational organizations and then do not question whether their money is not destined for purchase of shares of the same, or of those who aim to redistribute wealth among all risking inevitably provoking more widespread poverty. Therefore, each individual is required to make a conscious use of economic resources, in other words to be aware of the responsibility-or the consequence-inherent in his own action or not to act.

Again, on the relationship between the ethics of intention and the ethics of responsibility, it is interesting how Stiglitz maintains: "Ethics is about relationships between individuals, with the community and with society in general. In functioning communities, it includes recognized moral standards of cohabitation: it is wrong to kill, assault or harm others in any way. Instead, in modern societies, it is possible to do it in many different ways: by disseminating waste, for example, it compromises the environmental balance and, therefore, the well-being of the community. Simple maxims such as 'do unto your neighbor what you would have done to you' or 'do not do to your neighbor what you would not have done to you' and principles such as Kant's categorical imperative, provide widely accepted directives, though, surely, the world is so complex that their application, in particular circumstances, can result not start or even ambiguous" (Stiglitz, 2003: pp. 69-78). Stiglitz, in the aforementioned article, 
returns to attention to the consequences of economic action, observing that "economic policies are often adopted by paying insufficient attention to the consequences (...) and this represents a violation of fundamental ethical principles".

But there can be no responsibility if there is no freedom Hayek claims, the responsibility is in fact proportional to the degree of freedom that an individual enjoys. "Freedom does not just mean that the individual has both the possibility and the burden of choice; it also means that he must suffer the consequences of his actions and that for them he will encounter blame or praise. Freedom and responsibility are inseparable" (Hayek, 1999: p. 111). “The determinists-he observes-generally argue this way: since human actions are determined completely by natural causes, it is absolutely unjustified to consider men responsible and praise them or blame them for their actions. The volunteers, on the other hand, proclaim that man is an agent foreign to the cause-effect chain and therefore this agent is responsible and rightly is the object of praise or blame" (Hayek, 1999: p. 113). Man is therefore not subject to a deterministic order, but if he acts in a free society, he can choose and therefore succeed or make mistakes. "Free society requires a sense of responsibility from the man in his actions that goes beyond the duties required by law and also requires a general consensus on the point that individuals should be held responsible for both the success and failure of their actions. When men are enabled to do what they want, they must also be held accountable for the results of their efforts" (Hayek, 1999: p. 116).

"The complementarity of freedom and responsibility-says Hayek again-means that the arguments in favor of freedom are valid only for those who can be held responsible; not for minors, the deficient, the insane. The assumption is the ability of the person to learn from experience and to guide his actions with the knowledge thus acquired (...). A person whose actions are totally determined by the same impulses, not controlled by the awareness $(\mathrm{cn})$ of the consequences, (...), could not be held responsible (...)" (Hayek, 1999: p. 117). Therefore, for Hayek there is no responsibility without freedom. But then it could be assumed that excessive interference by the State in the life of citizens can constitute a limitation of their freedom, and therefore causes a less sense of responsibility, that is a limited awareness of the consequences of their actions and the impact that every individual choice can have on social life.

Therefore, a state that is basically omnivorous in social issues tends to obscure individual awareness, yet it is often considered the only one capable of providing social well-being. To this idea we believe we can reply with the words of Pascal Salin that "there can only be two types of individual action in a society: either social cooperation, which implies the exchange of free will between free individuals, or coercion, be it physical or legal. Well, one of the greatest and most frightening successes of the modern state consists in the fact that it succeeded in making believe that 'social cooperation' necessarily implied its intervention" (Salin, 2002: p. 105). 


\section{Cooperation against Competition: A Still Unresolved Dispute}

A recurring prejudice about ethical finance is that 'collaboration and cooperation should replace competition and competition' in the underlying idea that cooperation and competition are on antithetical positions. It is the ancient attack on the market of those who consider it a complex cause of social inequality. Well, we would like to oppose to this prejudice the thesis that competition is the highest form of cooperation and that "we must abandon the idea that fair competition and mutual collaboration are antithetical objectives and condemned to exclude each other" (Tagliagambe, 1994: p. 106). Competition is a process of discovery, says Hayek, "to consider competition as the opposite of cooperation (...) would be to understand its nature" (Hayek, 1999: p. 67). The idea that cooperation should replace competition is based on several false principles: first, it requires a broad agreement on the ends; secondly, it presupposes that man, "left free", pursues only selfish ends; thirdly, it considers the market a place of subtraction of resources from the strongest to the weakest; finally, it ignores the characteristics of spontaneous orders.

"Cooperation, like solidarity-observes Hayek-presupposes a broad agreement on the goals, as well as on the methods used for their pursuit. It makes sense in a small group whose members share particular habits, knowledge and beliefs about what can be done, but it makes little sense when the problem is to adapt to unknown circumstances; yet it is precisely this adaptation to the unknown that underpins the coordination of efforts in an extended order. Competition is a procedure of discovery, a procedure involved in all evolution, which has led man to involuntarily respond to new situations; and it is with more competition, not through agreements that we gradually increase our efficiency" (Hayek, 1997: p. 52).

The idea of replacing cooperation with competition is therefore simply a misguided question that does not take into account the impossibility in the Great Society to know the ends of all individuals. In this regard, Hayek says that "the request to restrict the action of individuals to the deliberate pursuit of known and observable beneficial purposes is in part a remnant of the instinctive and cautious micro-ethics of the small group, where the perceived aims were jointly directed to the visible needs of personally known comrades (this means: solidarity and altruism)" (Hayek, 1997: p. 140).

And even more clearly, Hayek marks the difference between the morality of small communities and the morality of the extended order. "First of all there is (...) the so-called innate morality of our instincts (solidarity, altruism, group decisions and the like) and the practices that arise from it, but these are not sufficient to sustain our current extended order, and its population. Secondly, there is the evolved morality (saving, private property, honesty and so on) that created and sustains the extended order. The extended order depends on this morality, in the sense that it arose from the fact that the groups that followed the funda- 
mental rules of this morality have increased in number and in welfare compared to the other groups. The paradox of our extended order and the market-and the stumbling block for socialists and constructivists-is that, through this process, we are able to provide, with the resources available (and indeed, in that same process, to discover more resources ) to more people than would be possible through an intentional direct process" (Hayek, 1997: pp. 125-126).

But to do this it is necessary that there be freedom. "Freedom is essential to make room for the unpredictable and unpredictable; we need it because, as we have learned, opportunities arise for it to achieve many of our goals. As every individual knows little, and in particular, rarely knows who of us can do better, we rely on the independent and competing efforts of many, to propitiate the birth of what we desire when we see it" (Hayek, 1999: p. 60).

It is wrong to believe that only the State can guarantee social welfare and that the individual left free would follow only selfish ends. Hayek clarifies this point by saying that "there is a great misunderstanding about the ideal that a person should pursue: it is believed that left free of himself, he will pursue or should pursue only selfish purposes. The freedom to pursue one's goals, however, is just as important for a very selfless person (...) as for all selfish people. It is part of ordinary human nature, in men and perhaps even more so in women, and is one of the most important conditions for their happiness, to be able to do the good of others their main purpose (...). However, altruism, in general, is a meaningless concept. No one can care about others as such: the responsibilities that we must assume must always be particular, can only affect those whose concrete facts we know and to which both for choice and for special conditions, we are attracted. It is one of the fundamental rights and duties of a man to decide what and what needs of another are for him the most important ones" (Hayek, 1999: p. 119).

This recalls the pluralism of values whose ethical investments are also interpreted, responding to the ethical demands of different groups.

So it is not possible to agree on the goals, consequently, compliance with the rules becomes necessary. "To operate in a beneficial way, competition requires that those who are competitors observe the rules rather than resort to physical force. Only the rules can unify an extended order. Common ends can only do so during a temporary emergency that creates a common danger for everyone; 'the moral equivalent of war', offered to evoke solidarity, is only a relapse into more primitive social principles” (Hayek, 1999: p. 119).

And yet "what makes agreement and peace possible in this society is that individuals are asked to agree on the means, not the ends; means that are able to serve a great variety of purposes, and from which everyone hopes to be assisted in the pursuit of his own purposes" (Hayek, 1994: p. 188).

"The market is nothing more than an abstract space with which we designate all the transactions between individuals" (Salin, 2002: p. 104). Social cooperation is based on free trade through which everyone gets something in return for something else. "But what he gets has more value for him than he gives-observes 
Salin-in fact, to the extent that the exchange takes place between free individuals, nobody is obliged to accept it and, if this takes place, it is necessarily because it increases the satisfactions of both. Thus, we can say in all certainty, without the need for verification, that exchange necessarily creates value and that it is necessarily beneficial for the two parties. But the value created is purely subjective, that is, it falls within the sphere of the perception of the two actors of the exchange: each gains from the exchange, otherwise, being rational, he would not make the transaction" (Salin, 2002: pp. 107-108).

If the market price, that is the value of things, can be measured, the same can not be done with the subjective value that is the one that produces satisfaction in both the subjects of the transaction, therefore the price does not quantify the satisfaction.

The market is exchange and "catallassi is a global order superior to any desired form of organization precisely because men, pursuing their interests, both in a completely selfish and altruistic manner, support the goals of many other individuals who will remain largely unknown" (Hayek, 1994: p. 318).

"Market morale leads us to benefit others, not through our intentions, but by acting in such a way that, in any case, it will have this effect. The extended order overrides individual ignorance (...) in a way that good intentions can not do, and therefore makes our efforts altruistic in their effects" (Hayek, 1997: p. 141).

\section{Against the Demonization of "Profit"}

A second recurring prejudice is that according to which ethical finance can replace the maximization of social utility to the maximization of individual profits.

We would like to distance ourselves from those who believe, erroneously in our opinion, that "pursuing personal interests is morally wrong". The ethical investment is not an investment in loss and on the other hand we remember with Adam Smith that "it is not from the benevolence of the butcher, brewer and baker that we expect our dinner, but from the consideration that these have for their own personal interest. We do not turn to their humanity, but to their selfishness and to them we talk about their advantages and not about our needs".

"Men exchange objects, services, but also signs of affection or friendship. All this constitutes human activity, without it being possible to separate in each man a part that would be 'economic' and another that would not be, a part that would depend on economic science and another that would depend on sociology, psychology or even from poetry and theology. In a sense, economic science does not exist, only the science of human activity exists. It will be realized that the accusation often made to liberal economists to be 'materialistic', to pay attention only to the 'economic' aspect of things, to profit to money is absurd. In fact, only true liberals have understood that material objects-economic sayings-are but means, like others, to reach the specific ends of each one, whether these are of a material, ethical, religious or philosophical nature" (Salin, 2002: pp. 108-109).

And taking up Hayek: "The contempt of profit is due to ignorance, or an admirable attitude, if we want, in the ascetic, which has chosen to settle for a small 
part of the riches of this world, but if this scorn becomes concrete forms of restrictions to the profit of others, it would be nothing but a feeling of selfishness, as it would impose asceticism, that is to say, privations of all kinds, to others" (Hayek, 1997: p. 176).

And yet "prices and profits are all that producers need in order to be able to pursue more effectively the ends of men who do not know. They are research tools-just like the spyglass is the tool that extends the field of view for the soldier or hunter, sailor or pilot. The market process gives most people the material and information resources to get what they want" (Hayek, 1997: p. 176).

Thus profit and profitability are the parameters for judging the validity of entrepreneurial action.

Michael Novak points out that one of the mistakes made in relation to market morality is to believe that the desire to improve one's material conditions is greed because what is needed for improvement already belongs to others. Well, the error of such thinking resides for Novak in considering wealth "as a fixed sum, already internally distributed, and ignoring the dimension of invention, discovery and creation of new wealth: it means, in short, to imagine that any form of growth of wealth involves 'taking away' something from someone" (Novak, 1992). And what was also said about the stock exchange, which is not a zero-sum game, but a positive sum in the sense that it creates new wealth.

\section{Conclusion}

This work was intended to make a contribution to understand the reasons why ethical finance does not receive the success that would be expected, especially given the increasingly evident need for a socially responsible approach to economics and finance.

Using the paradigm of methodological individualism and, in particular, the concepts of individual responsibility, personal freedom, human action and unintended consequences, we wanted to eradicate some of the prejudices related to ethical finance and we formulated hypotheses that could clarify why sometimes the investor does not feel "invested" with the responsibility of being himself the engine of change.

The research takes into consideration only some of the possible causes; the future objectives of economic and environmental sustainability should stimulate further reflections to remove the obstacles that impede the full success of financial instruments of an ethical and socially responsible nature.

\section{References}

Bedogni, G. (2002). Per un profilo etico dei prodotti finanziari. In AA. VV. (Ed.), Responsabilità sociale dell'impresa e finanza etica. Milano: EGEA.

Hayek, F. A. (1994). Legge, legislazione e libertà. Milano: il Saggiatore.

Hayek, F. A. (1997). La presunzione fatale. Milano: Rusconi.

Hayek, F. A. (1999). La società libera. Edizioni Seam. 
Menger, C. (1997). Sul metodo delle scienze sociali. Macerata: Liberilibri.

Mises, L. (1959). L'azione umana.Torino: UTET.

Novak, M. (1992). Otto argomenti sulla moralità del mercato, Convegno su "God and the Marketplace". Newcastle-upon-Tyne.

Salin, P. (2002). Liberalismo. Soveria Mannelli: Rubbettino.

Stiglitz, J. E. (2003). I Paesi poveri e l'etica dei potenti. In Vita e Pensiero 2, (pp. 69-78). Estratto dalla relazione tenuta all'American Development Bank di Washington nel Novembre 2002.

Tagliagambe, S. (1994). Economia ed etica nei sistemi aperti. In AA.VV. (Ed.), Etica della solidarietà ed economia di mercato. Roma: Borla.

Weber, M. (1999). La politica come professione. In Il lavoro intellettuale come professione. Torino: Einaudi. 